\title{
Corrosion Inhibition of Aluminium by Treculia Africana Leaves Extract in Acid Medium
}

\author{
P.M. Ejikeme, ${ }^{a,}$ S.G. Umana ${ }^{a}$ and O.D. Onukwuli ${ }^{b}$ \\ ${ }^{a}$ Biomass and Industrial Chemistry Research Laboratory, Department of Pure and Industrial \\ Chemistry, University of Nigeria, Nsukka, Nigeria \\ ${ }^{b}$ Department of Chemical Engineering, Nnamdi Azikiwe University, Awka, Nigeria
}

Received 30 May 2012; accepted 31 October 2012

\begin{abstract}
The inhibitive effect of Treculia Africana leaves extract (TALE) in the corrosion of aluminium in $\mathrm{HCl}$ solution was studied using weight loss and thermometric methods at $30-60{ }^{\circ} \mathrm{C}$. The results showed that TALE acted as a corrosion inhibitor of aluminium in $\mathrm{HCl}$. Inhibition efficiency increased with increase in TALE concentration, but decreased with increase in temperature. TALE interaction with the metal surface was found to obey Freundlich and El-Awady adsorption isotherms. The obtained heats of adsorption values were negative. A phenomenon of physical adsorption is proposed for the adsorption behavior of TALE.
\end{abstract}

Keywords: weight loss, aluminium, heat of adsorption, activation energy, adsorption isotherm.

\section{Introduction}

Corrosion can be viewed as the process of returning a metal to its natural state, i.e., the ores from which it was originally obtained. Corrosion involves oxidation of the metal. Since corroded metal often losses its structural integrity and attractiveness, this spontaneous process has great economic impact. Approximately one-fifth of the iron and steel produced annually is used to replace rusted metal [1]. Metals corrode because they move to a thermodynamically stable state. For metals to corrode, they have to react with their environment. According to Obot et al. [2], a general mechanism for the dissolution of $\mathrm{Al}$ metal would be similar to that reported in the literature as given in Eqs. 1-5:

$$
\begin{aligned}
& \mathrm{Al}(\mathrm{s})+\mathrm{H}_{2} \mathrm{O} \leftrightarrows \mathrm{AlOH}_{\mathrm{ads}}+\mathrm{H}^{+}+\mathrm{e} \\
& \mathrm{AlOH} \mathrm{H}_{\mathrm{ads}}+5 \mathrm{H}_{2} \mathrm{O}+\mathrm{H}^{+} \leftrightarrows \mathrm{Al}^{3+} \cdot 6 \mathrm{H}_{2} \mathrm{O}+2 \mathrm{e} \\
& \mathrm{Al}^{3+}+\mathrm{H}_{2} \mathrm{O} \leftrightarrows[\mathrm{AlOH}]^{2+}+\mathrm{H}^{+}
\end{aligned}
$$

\footnotetext{
* Corresponding author. E-mail: paul.ejikeme@unn.edu.ng, ejikemepaul13@yahoo.com
} 


$$
[\mathrm{AlOH}]^{2+}+\mathrm{X}^{-} \leftrightarrows[\mathrm{AlOHX}]^{+}
$$

The controlling step in the metal dissolution is the complexation reaction between the hydrated cation and the anion present, Eq. (3). In the presence of chloride ions, the reaction will correspond to Eq. 5 and the soluble complex ion formed increases the metal dissolution rate which depends on the chloride concentration.

$$
[\mathrm{AlOH}]^{2+}+\mathrm{Cl}^{-} \rightarrow[\mathrm{AlOHCl}]^{+}
$$

Corrosion of oil equipment is of significant cost, which is additional to mechanical and other operational problems that require work-over and repairs. It is therefore imperative to add corrosion inhibitors to the solution during pickling in order to reduce the degree of metal attack and the rate of acid consumption [3]. A lot of research has been done with naturally occurring substances since they are known to be eco-friendly and with little or no side effect on the humans. Among the naturally occurring substances reported in the corrosion study of metals like aluminum, tin and mild steel, there are leave extracts, gums and exudates, dyes, oils from plant materials, plant seeds and fruits, and anti-bacterial drugs.

Plant extracts like the aqueous extract of Fenugreek leaves [4]; Calendula Officinalis flower [5]; aqueous extract of Olive leaves [6]; Sansevieria Trifasciata extract [7]; Mangrove tannins and their flavanoid monomers [8]; Ocimum Basilicum extract [9]; and ficus extract [10] have been studied. Also, Obot et al. [11] and Umoren et al. [12] have studied ginseng root and Raphia hookeri, Vigna Unguiculata [3] and exudate gum from Dacroydes Edulis [13], and established their corrosion inhibition effects. They were all found to be good corrosion inhibitors with no effect on the environment.

Raja et al. [14] reported that the adsorption of green inhibitors could occur through the formation of a bond with the metal, involving the sharing of the lone pair of electrons of alkaloids constituents $(-\mathrm{NH},-\mathrm{OH}$, and $\mathrm{C}=\mathrm{O})$ present in the neutral alkaloid molecule and the metal. Adsorption of mangrove tannins and their flavonoid monomers have been reported [8] to proceed via sharing of the donor group $(-\mathrm{OH})$ electrons or aromatic $\pi$ - electrons between the flavonoid molecules and the metal. The inhibitive properties of tannins have been attributed to the reaction of the polyphenolic fraction of the tannins moieties, which ensures effective protection of the metal surfaces [15]. The triterpenoid constituents also possess functional groups which are capable of chelating with aluminium ions and thus facilitate strong coordination on the alloy surface [15].

Treculia Africana (African breadfruit) is a tree plant that has been explored traditionally for its medicinal value [16]. In spite of the broad spectrum of inhibitors chosen from organic compounds, it is significant to note that the search for corrosion inhibitors that have optimum efficiency is still going on [17]. The aim of the present work therefore is to assay the phytochemicals present in TALE and investigate its inhibitive properties on aluminium at $30^{\circ} \mathrm{C}$ and $60{ }^{\circ} \mathrm{C}$ through weight loss and thermometric methods. 


\section{Experimental}

Aluminium, type AA 1060, was purchased at System Metals Industries Limited, Calabar, Nigeria, and it was of $98 \%$ purity. It was subsequently cut into coupons of the required sizes. UV-visible spectrophotometer (Sperctro 21D) PEC Medicals, U.S.A., was used to measure the solution absorbances. All the reagents used were of analytical grade, unless otherwise stated.

\section{Plant extract}

Sun-dried and powdered leaves of Treculia Africana (300 g) were macerated in $96 \%$ ethanol at room temperature for 3 days in a column and concentrated to a dark green residue using a rotary evaporator. 0.1-0.5 $\mathrm{g}$ of the extract were weighed using an analytical grade balance and dissolved in 1 molar of the corrodent concentration. The phytochemicals screening of the plant extracts were carried out according to the methods reported by Evans [18] and Harborne [19].

\section{Weight loss method}

In this method, previously cleaned aluminum coupons (degreased with ethanol, dipped in acetone, allowed to dry in the air and preserved in a desiccator) were weighed and suspended with the aid of glass rod and hook in an open beaker containing $100 \mathrm{~mL} 1 \mathrm{M} \mathrm{HCl}$ solution. The beaker was placed in a water bath maintained at temperatures of $30{ }^{\circ} \mathrm{C}$ or $60^{\circ} \mathrm{C}$ and in each case lightly closed with an aluminium foil. The procedures were conducted with and without the various concentrations of the plant extract.

After $2 \mathrm{~h}$, the metal specimens were withdrawn from the test solution, washed, dried and re-weighed. The weight loss was taken as the difference in weight of the specimen before and after immersion determined by weighing with a digital balance. The experiment was conducted progressively for $8 \mathrm{~h}$. The tests were conducted in triplicate to guarantee the reliability of the results and the mean value of the weight loss was reported.

An assessment of corrosion rates and inhibition efficiency for aluminium with different inhibitor concentrations was computed as follows:

Corrosion rate $(W)$

The corrosion rate $(\mathrm{W})$ was computed using Eq. 6:

$$
\mathrm{W}=\mathrm{M}_{1}-\mathrm{M}_{2} / \mathrm{A} . \mathrm{t}
$$

where $\mathrm{M}_{1}=$ weight $(\mathrm{g})$ before immersion, $\mathrm{M}_{2}=$ weight $(\mathrm{g})$ after immersion, $\mathrm{A}=$ area $\left(\mathrm{cm}^{2}\right)$ of the specimen, and $\mathrm{t}=$ exposure time $(\mathrm{h})$.

Inhibition efficiency (\%I)

The inhibition efficiency (\%I) of the extract was evaluated using equation 7:

$$
\% \mathrm{I}=\left[\mathrm{W}_{\text {blank }}-\mathrm{W}_{\text {inh }} / \mathrm{W}_{\text {blank }}\right] \times 100
$$

where: $\mathrm{W}_{\text {blank }}=$ corrosion rates in the absence of inhibitor and $\mathrm{W}_{\mathrm{inh}}=$ corrosion rates in the presence of inhibitor. 


\section{Thermometric measurements}

The reaction vessel and procedure for determining the corrosion behavior by this method has been described elsewhere by other authors [3, 13, 20]. In the thermometric measurement the $\mathrm{HCl}$ (corrodent) concentration was kept at $2 \mathrm{M}$ while the volume of the test solution used was $100 \mathrm{~mL}$. The initial temperature in the experiment was kept at $32{ }^{\circ} \mathrm{C}$. The process of the corrosion reaction was monitored by determining the changes in temperature with time using a standard digital thermometer. This method enables the computation of the reaction number $(\mathrm{RN})$ which is given in Eq. 8:

$$
\mathrm{RN}\left({ }^{\circ} \mathrm{C} \min ^{-1}\right)=\mathrm{T}_{\mathrm{m}}-\mathrm{T}_{\mathrm{i}} / \mathrm{t}
$$

where: $T_{m}$ and $T_{i}$ are the maximum and initial temperatures, respectively; $t$ is the time (min) taken to reach the maximum temperature.

The inhibition efficiency was evaluated from percentage reduction in the RN using Eq. 9.

$$
\% \mathrm{IE}=\left[\mathrm{RN}_{\mathrm{aq}}-\mathrm{RN}_{\mathrm{wi}} / \mathrm{RN}_{\mathrm{aq}}\right] \times 100
$$

where: $\mathrm{RN}_{\mathrm{aq}}=$ reaction number in the absence of inhibitor (blank solution); $\mathrm{RN}_{\mathrm{wi}}$ $=$ reaction number of $2 \mathrm{M} \mathrm{HCl}$ containing the studied inhibitor (TALE).

\section{Results and discussion}

\section{Phytochemicals in TALE}

The result of the phytochemical investigation is given in Table 1 . It could be seen from the table that the extract contains large proportions of phenols, terpenes, flavonoid and tannins as well as deoxy sugar and proteins. These compounds contain hetero-atoms which have been noted to act as good inhibitors since they form chemical bonds with empty d-orbitals in metals [21].

Table 1. Phytochemicals present in Treculia Africana leaves extracts.

\begin{tabular}{|l|c|c|}
\hline Phytochemical & TALE (Qualitative) & TALE (mg/100g) (Quantitative) \\
\hline Tannins & +++ & 1122 \\
\hline$\beta$-carotene & ++ & 93.2 \\
\hline Cardiac glycoside & ++ & 2.4 \\
\hline Flavonoid & +++ & 1395.04 \\
\hline Deoxy sugar & ++ & 5218 \\
\hline Terpenes & +++ & 4256.8 \\
\hline Steroid & ++ & 162.75 \\
\hline Alkaloids & +++ & 266.8 \\
\hline Phenol & ++ & 75000 \\
\hline Protein & +++ & 2906.8 \\
\hline
\end{tabular}

TALE is thus a complex mixture of alkaloids, flavonoids, terpenes, and protein. Other components include steroids, cyanogenic glycoside, phenols, carbohydrates, and $\beta$-carotene, tannins, anthraquinone and other phytochemical constituents which have been found to be good corrosion inhibitors [22].

TALE components like alkaloids, cyanogenic glycosides, amino groups are known to contain heteroatoms such as nitrogen and oxygen in their molecules [19]. These heteroatoms have been reported to function as effective inhibitors of metals and alloys corrosion in different aggressive environments [9,14,23,24]. 
The corrosion inhibition of the metal under study may be attributed to the adsorption of TALE components through these atoms which are regarded as centers of adsorption [11] onto the metal surfaces. The net effect of the adsorption of the extract through the heteroatoms (in its phytochemicals) is the protection of the metal surfaces from the attack of the aggressive ions $\left(\mathrm{Cl}^{-}\right)$of the acid. However, owing to the complex chemical composition of TALE, it is difficult to assign the inhibitive effect to a particular phytochemical constituent.

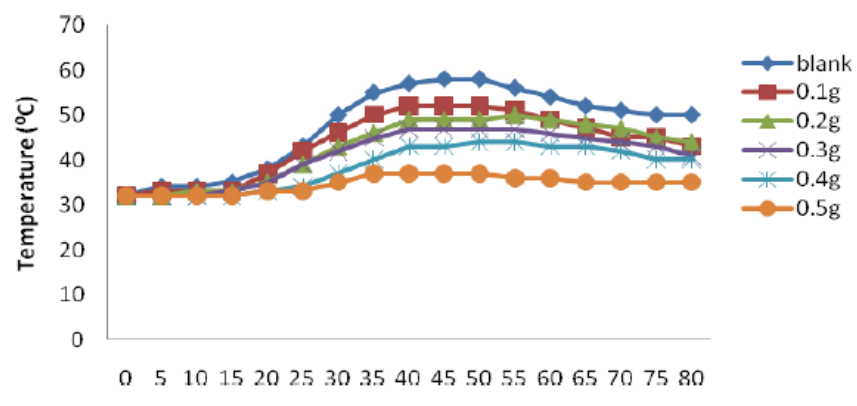

Time (min)

Figure 1. Temperature-time curves for the dissolution of aluminium in blank and different concentrations of TALE.

\section{Effect of change in concentration and temperature}

The effect of using different concentrations of the extract on the change in temperature of the corrosion medium is shown in Fig. 1. From the figure, as the concentration of the inhibitor increases, the time required to reach maximum temperature of the corrosion medium increases and the rate of temperature rise decreases. This could be a result of the fact that as the concentration of the inhibitor increases, more surface of the metal is covered by adsorption of the inhibitor leading to overall less dissolution of the metal and the attendant rise in temperature. Dahmani et al. [25] reported that increase in inhibitor concentration led to a decrease in the corrosion rate. This effect is corroborated by the decrease in the reaction number with increase in concentration, as shown in Fig. 2.

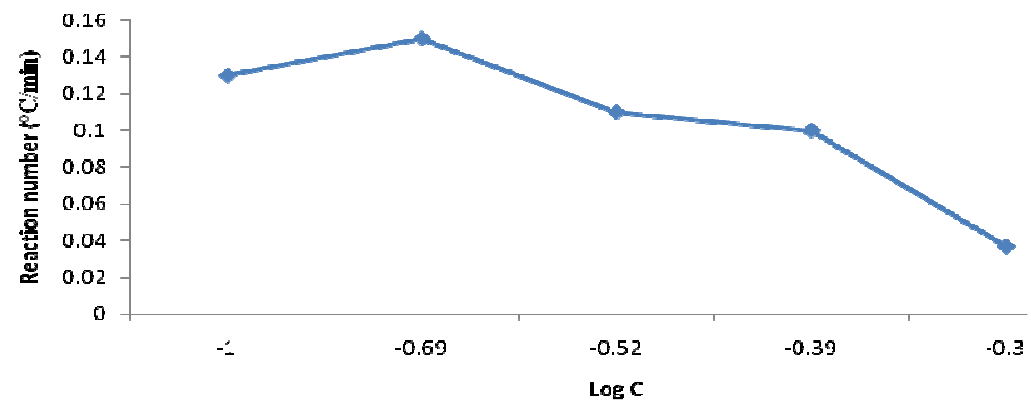

Figure 2. Plot of the reaction number $(\mathrm{RN})$ against Log of the inhibitor concentration (C). 
Figs. 3 and 4 show the plot of weight loss against time for aluminium corrosion in $1 \mathrm{M} \mathrm{HCl}$ with TALE at 30 and $60{ }^{\circ} \mathrm{C}$. From the plots it is seen that the weight loss increases with time, with the highest weight loss gotten at $8 \mathrm{~h}$ at both room $\left(30{ }^{\circ} \mathrm{C}\right)$ and elevated temperature $\left(60^{\circ} \mathrm{C}\right)$. It reduces with increase in the extract concentration, with the highest reduction obtained with $0.5 \mathrm{~g}$ of the extract. Similar results have been reported by other authors $[25,26]$.

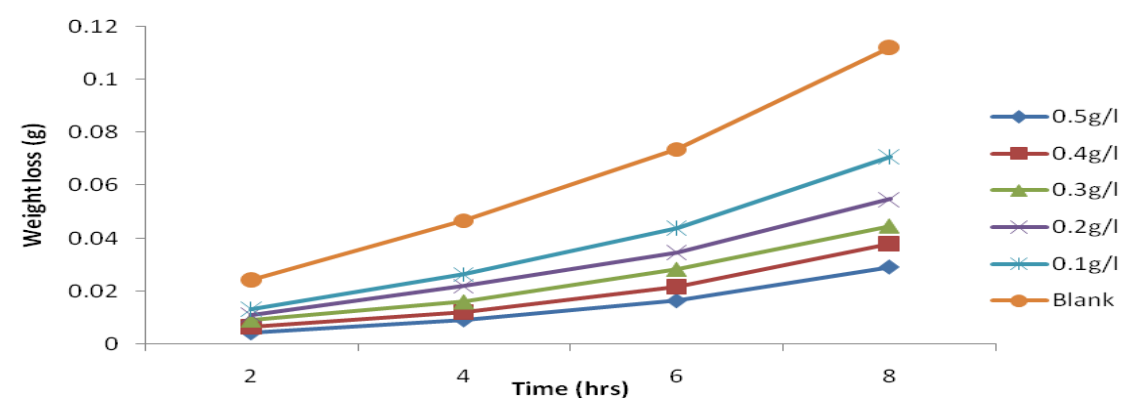

Figure 3. Plot of weight loss against time for aluminium corrosion in $1 \mathrm{M} \mathrm{HCl}$ with TALE at $30^{\circ} \mathrm{C}$.

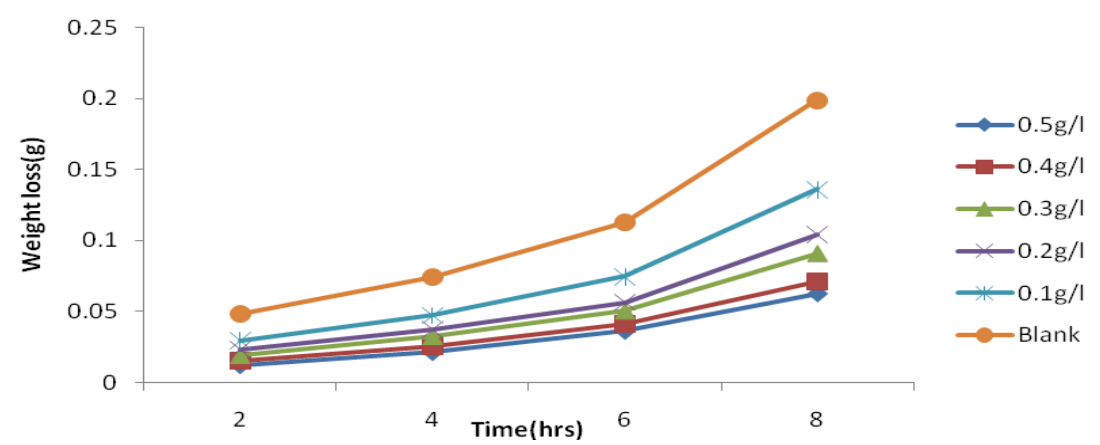

Figure 4. Plot of weight loss against time for aluminium corrosion in $1 \mathrm{M} \mathrm{HCl}$ with TALE at $60{ }^{\circ} \mathrm{C}$.

Fig. 5 shows the plot of inhibition efficiency against concentration. It is seen that the inhibition efficiency increases with the extract concentration, but reduces with increase in temperature. From Table 2, the highest inhibition efficiency of $74.17 \%$ was achieved with $0.5 \mathrm{~g}$ of the extract at $30^{\circ} \mathrm{C}$, while that obtained at 60 ${ }^{\circ} \mathrm{C}$ was $68.70 \%$ (lower than the former). We inferred from the forgoing that thermal motion may be responsible for the decreased inhibition efficiency at 60 ${ }^{\circ} \mathrm{C}$, as the molecules of the inhibitor will have higher kinetic energy and thus making it a little difficult for adsorption to take place.

James and Akaranta [27,28] attributed this observation to the general rule guiding the rate of chemical reaction, which says that chemical reaction increases with increasing temperatures. They also noted that an increased temperature favours the formation of activated molecules, which may be doubled in number, with $10{ }^{\circ} \mathrm{C}$ rise in temperature, thereby increasing the reaction rate. An increase in temperature may also increase the solubility of the protective films on the metals, thus increasing the susceptibility of the metal to corrosion [29]. 


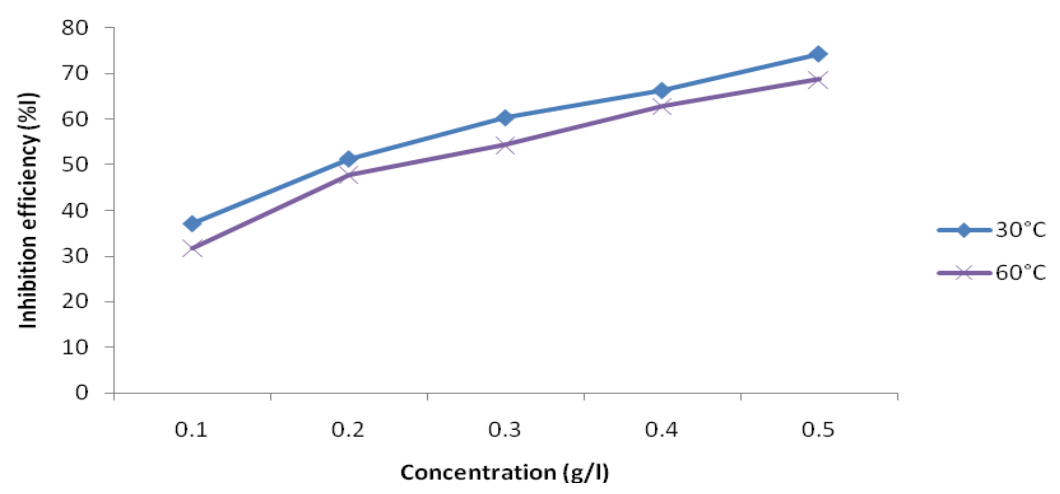

Figure 5. Plot of inhibition efficiency against concentration for aluminium corrosion in $1 \mathrm{M} \mathrm{HCl}$ with TALE.

Table 2. Calculated values of the corrosion parameters for aluminium corrosion in $1 \mathrm{M}$ $\mathrm{HCl}$ in the absence and presence of various concentrations of TALE at $30{ }^{\circ} \mathrm{C}$ and $60{ }^{\circ} \mathrm{C}$.

\begin{tabular}{|c|c|c|c|c|c|c|c|c|}
\hline \multirow{2}{*}{$\begin{array}{c}\text { System/ } \\
\text { concentration }\end{array}$} & \multicolumn{2}{|c|}{$\begin{array}{c}\text { Corrosion } \\
\text { rate } \mathrm{X10}^{-4}(\mathrm{mpy})\end{array}$} & \multicolumn{2}{|c|}{$\begin{array}{c}\text { Inhibition } \\
\text { efficiency }(\% \mathrm{I})\end{array}$} & \multicolumn{2}{|c|}{$\begin{array}{c}\text { Rate constant } \\
\left(\mathrm{sec}^{-1}\right) \times 10^{-3}\end{array}$} & \multirow{2}{*}{$\begin{array}{c}\text { Ea } \\
(\mathbf{k J} / \mathbf{m o l})\end{array}$} & \multirow{2}{*}{$\begin{array}{c}\text { Qads } \\
(\mathbf{k J} / \mathbf{m o l})\end{array}$} \\
\hline & $30^{\circ} \mathrm{C}$ & $60^{\circ} \mathrm{C}$ & $30^{\circ} \mathrm{C}$ & $60^{\circ} \mathrm{C}$ & $30^{\circ} \mathrm{C}$ & $60^{\circ} \mathrm{C}$ & & \\
\hline Blank & 50.13 & 88.88 & - & - & 0.030 & 0.027 & 15.2 & - \\
\hline $0.1 \mathrm{~g} / \mathrm{L}$ & 31.56 & 60.75 & 37.04 & 31.64 & 0.031 & 0.030 & 18.54 & -7.47 \\
\hline $0.2 \mathrm{~g} / \mathrm{L}$ & 24.46 & 46.40 & 51.20 & 47.76 & 0.033 & 0.030 & 17.95 & -4.44 \\
\hline $0.3 \mathrm{~g} / \mathrm{L}$ & 19.95 & 40.62 & 60.19 & 54.29 & 0.032 & 0.030 & 19.67 & -6.89 \\
\hline $0.4 \mathrm{~g} / \mathrm{L}$ & 16.96 & 31.64 & 66.16 & 62.83 & 0.035 & 0.032 & 17.78 & -4.89 \\
\hline $0.5 \mathrm{~g} / \mathrm{L}$ & 12.94 & 27.81 & 74.17 & 68.70 & 0.035 & 0.031 & 20.99 & -8.17 \\
\hline
\end{tabular}

\section{Adsorption isotherm modeling}

The establishment of adsorption isotherms that describe the adsorption of a corrosion inhibitor can provide important clues to the nature of the metalinhibitor interaction [2]. Adsorption of the organic molecules occurs as the interaction energy between molecule and metal surface is higher than that between the $\mathrm{H}_{2} \mathrm{O}$ molecule and the metal surface [30].

\section{El-Awady adsorption isotherm}

The characteristics of the isotherm are given in equation 10 .

$$
\log \theta / 1-\theta=\log K_{a d}+y \log C
$$

where: $\mathrm{C}$ is the concentration of the TALE; $\theta$ is the degree of surface coverage; $\mathrm{K}_{\mathrm{ad}}$ is the equilibrium constant of adsorption process $=\mathrm{K}^{1 / \mathrm{y}}$.

In this model, the number of active sites $\mathrm{y}$ is included. Values of $1 / \mathrm{y}<1 \mathrm{imply}$ multilayer adsorption, while values $1 / \mathrm{y}>1$ suggest that a given inhibitor molecule occupied more than one active site. The plot of $\log \theta / 1-\theta$ against $\log C$ (Fig. 6) gave a straight line at each temperature with $\mathrm{R}^{2}$ values of minimum of 0.98 . The values $1 / \mathrm{y}$ and $\mathrm{K}_{\mathrm{ad}}$ calculated from the El-Awady et al. model curve are given in Table 3. From the table, the obtained values of $1 / y$ were greater than one, indicating that a given extract molecule occupied more than one active site [2]. 
Table 3. Derived values from El-Awady plot of aluminium corrosion in $\mathrm{HCl}$ with TALE.

\begin{tabular}{|c|c|c|c|c|}
\hline Temp $^{\mathbf{}} \mathbf{C}$ & $\mathbf{K}_{\text {ads }}$ & $\Delta \mathrm{G}_{\text {ads }}(\mathbf{k J} / \mathbf{m o l})$ & $\mathbf{1} / \mathbf{y}$ & $\mathbf{R}^{\mathbf{2}}$ \\
\hline 30 & 4.345 & -13.81 & 1.08 & 0.989 \\
\hline 60 & 4.325 & -15.17 & 1.01 & 0.995 \\
\hline
\end{tabular}

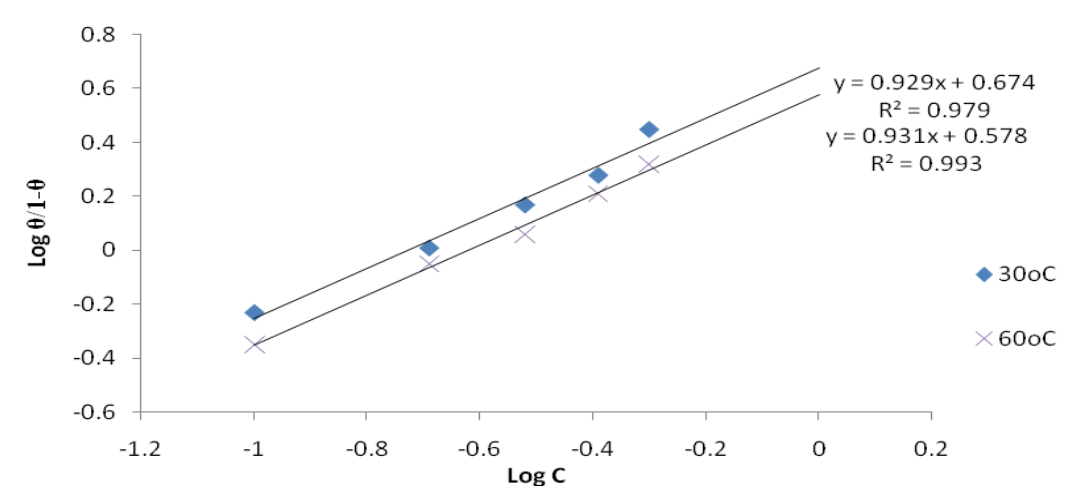

Figure 6. El-Awady adsorption isotherm for aluminium corrosion in $1 \mathrm{M} \mathrm{HCl}$ with TALE at $30-60^{\circ} \mathrm{C}$.

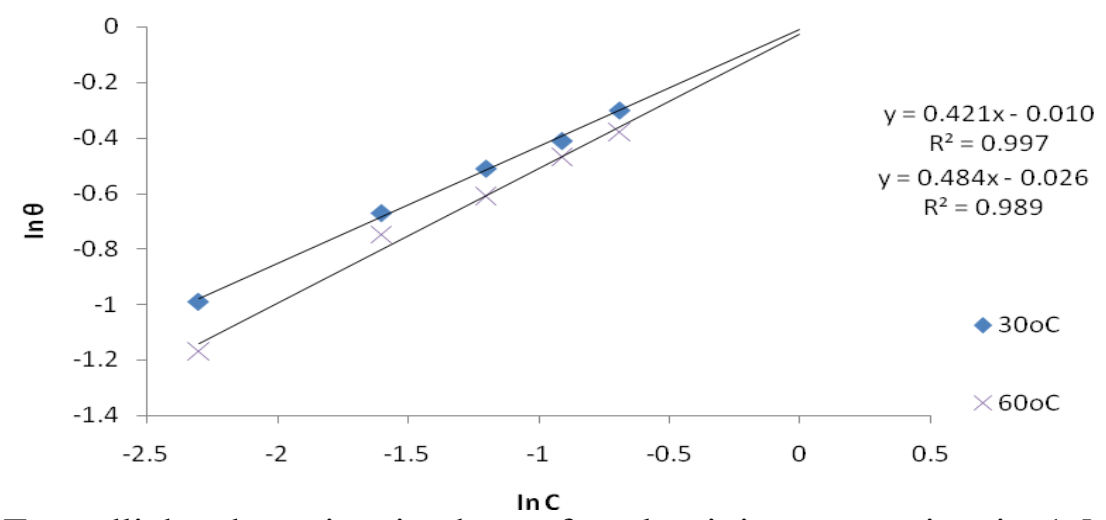

Figure 7. Freundlich adsorption isotherm for aluminium corrosion in $1 \mathrm{M} \mathrm{HCl}$ with TALE at $30-60^{\circ} \mathrm{C}$.

\section{Freundlich adsorption isotherm}

Freundlich adsorption isotherm was tested using equation 11 which could be written as equation of straight line (equation 12).

$$
\begin{aligned}
& \theta=\mathrm{KC}^{\mathrm{n}}(\text { where } 0<\mathrm{n}<\mathrm{I}) \\
& \ln \theta=\operatorname{InK}+\mathrm{n} \text { In } \mathrm{C}
\end{aligned}
$$

where: $\mathrm{K}$ represents the equilibrium constant of adsorption; $\mathrm{C}$ is the extract concentration.

A plot of $\ln \theta$ against $\ln \mathrm{C}$ (from Eq. 12) gave a straight line (Fig. 7) with high correlation coefficient (Table 4), which suggests that the experimental data also obeyed Freundlich adsorption isotherm.

The fit of the experimental data provides evidence for the role of adsorption in the observed inhibitive effect of the extract. 
Table 4. Derived values from Freundlich plot of inhibition of aluminium corrosion in $\mathrm{HCl}$ with TALE.

\begin{tabular}{|c|c|c|c|c|}
\hline Temp $^{\mathbf{}} \mathbf{C}$ & $\mathbf{K}_{\text {ads }}$ & $\boldsymbol{\Delta} \mathbf{G}_{\text {ads }}(\mathbf{k J} / \mathbf{m o l})$ & $\mathbf{n}$ & $\mathbf{R}^{\mathbf{2}}$ \\
\hline 30 & 1.025 & -10.179 & 0.421 & 0.997 \\
\hline 60 & 0.974 & -11.045 & 0.484 & 0.989 \\
\hline
\end{tabular}

\section{Kinetic and thermodynamic analysis}

Figs. 8 and 9 show the plot of $\log \Delta \mathrm{W}$ (change in weight) against time for the aluminium dissolution. From the plots, the values of the rate constant $(\mathrm{k})$ were evaluated. Linear plots were obtained, which indicates first order kinetics at both temperatures studied. First order kinetics has also been reported by James and Akaranta on the inhibition efficiency of acetone extract of red onion skin on aluminium in hydrochloric acid solutions [27].

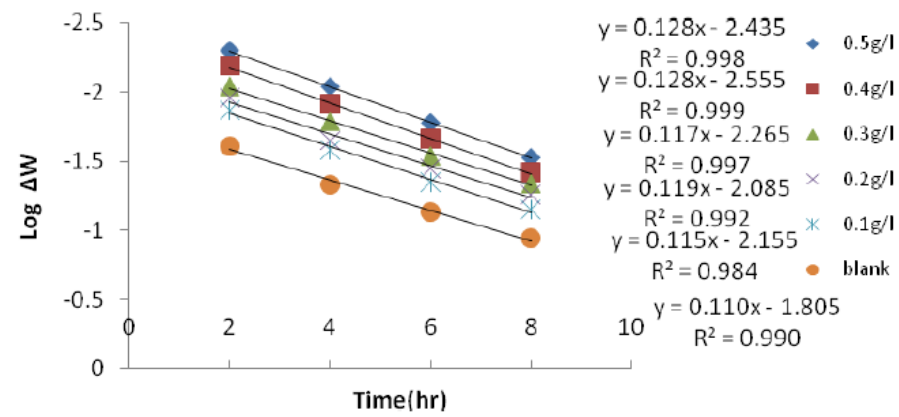

Figure 8. Plot of $\log \Delta \mathrm{W}$ against time for aluminium in $1 \mathrm{M} \mathrm{HCl}$ in the absence and presence of TALE at $30^{\circ} \mathrm{C}$.

\section{Heat of adsorption (Qads)}

The heats of adsorption $\left(\mathrm{Q}_{\mathrm{ads}}\right)$ were calculated using the following Eq. 13.

$$
\mathrm{Q}_{\mathrm{ads}}=2.303 \mathrm{R}\left\{\log \left[\theta_{2} / 1-\theta_{2}\right]-\log \left[\theta_{1} / 1-\theta_{1}\right]\right\} \times\left\{\left[\mathrm{T}_{1} \times \mathrm{T}_{2} / \mathrm{T}_{2}-\mathrm{T}_{1}\right]\right\}(\mathrm{kJ} / \mathrm{mol})
$$

where: $\theta_{1}=$ degree of surface coverage at temperature $\mathrm{T}_{1} ; \theta_{2}=$ degree of surface coverage at temperature $\mathrm{T}_{2} ; \mathrm{R}=$ universal gas constant.

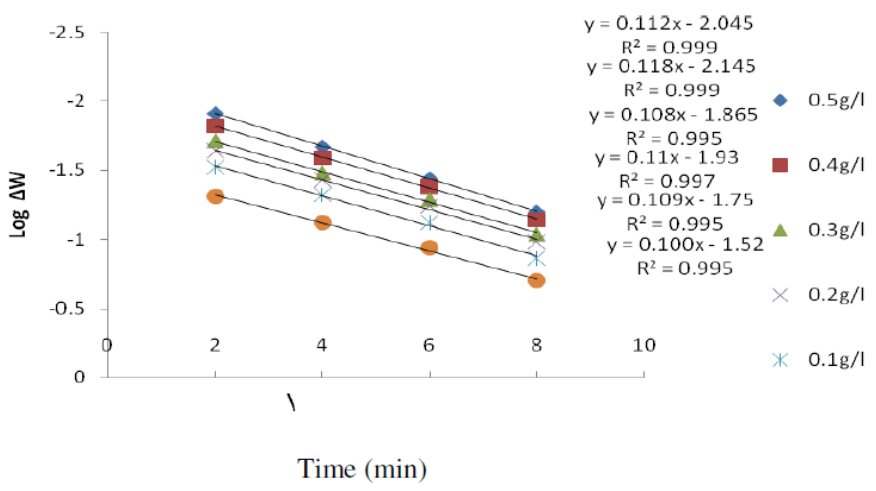

Figure 9. Plot of $\log \Delta \mathrm{W}$ against time for aluminium in $1 \mathrm{M} \mathrm{HCl}$ in the absence and presence of TALE at $60^{\circ} \mathrm{C}$.

The Qads values obtained (Table 2) were all negative. Negative $\mathrm{Q}_{\text {ads }}$ values are consistent with physisorption characteristics. The table also shows that inhibition efficiency decreases with increase in temperature. A positive value of Qads 
suggests decreased inhibition efficiency at higher temperature. From Table 2, it is evident that in all cases Qads followed a trend of negative values, which is consistent with the proposed inhibition mechanism with physisorption characteristics. Similar results had been reported by Oguzie et al. [9], Nnanna et al. [15] and Obot et al. [2].

\section{Activation energy}

The dependence of corrosion rate on temperature can be expressed by Arrhenius equation (equation 14):

$$
\log \mathrm{CR}=\log \mathrm{A}-\mathrm{Ea} / 2.303 \mathrm{RT}
$$

where: $\mathrm{CR}$ is the corrosion rate, $\mathrm{A}$ is the Arrhenius constant, $\mathrm{R}$ is a molar gas constant, and $\mathrm{T}$ is the absolute temperature.

A plot of $\log \mathrm{CR}$ against 1/T was made and a straight line was obtained with high correlation coefficients, as shown in Fig. 10. Activation energy (Ea) values, were calculated from the slope of the linear plot of Fig. 10 and are given in Table 2 for studies involving the blank and plant extracts. From Table 2, it is clear that Ea for the corrosion process in the presence of the extracts are higher than those in the absence of the extract (blank).

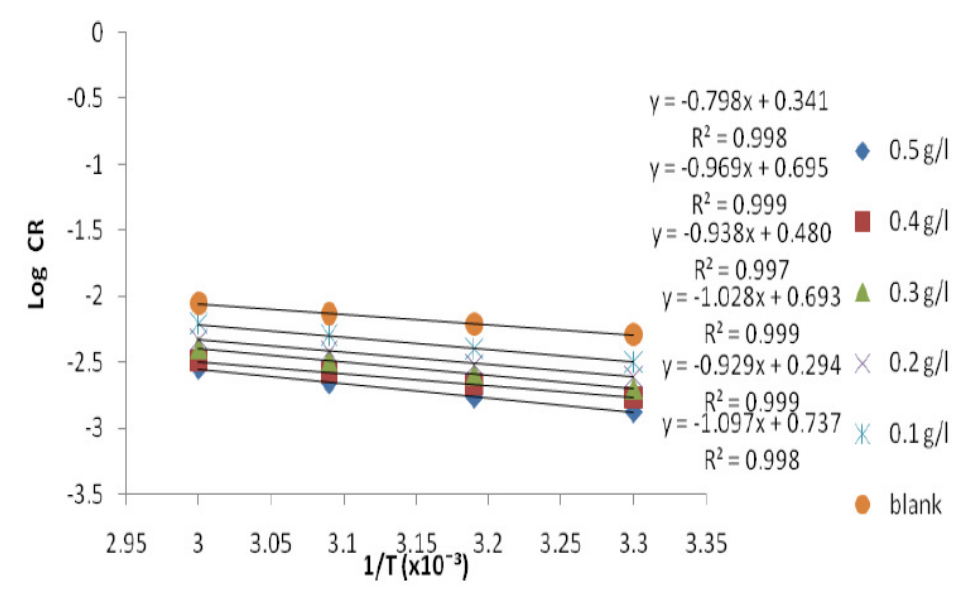

Figure 10. Arrhenius plot for aluminium corrosion in $1 \mathrm{M} \mathrm{HCl}$ in the absence and presence of TALE.

It is known that the Ea of the solution containing an inhibitor is higher than that of a solution without an inhibitor if the IE\% of an inhibitor decreases with increase in temperature. Also, if the IE\% of an inhibitor does not change with temperature variation; Ea does not change in the presence or absence of inhibitors [2], where the higher activation energies mean a slow reaction. The Ea values obtained for the Treculia africana leaves extracts were higher at all the concentrations studied relative to the blank, though they did not show a particular trend within the various concentrations, possibly due to the complexity of the extract. The increase in activation energy in the presence of the extract is often interpreted as physical adsorption with the formation of an adsorptive film with an electrostatic character [31]. This conclusion is denoted by the decrease in inhibition efficiency with increasing temperature (Table 2). However, increase in 
activation energy is proportional to the inhibitor concentration, indicating that the energy barrier for the corrosion process is also increased [31]. Similar results have been reported $[2,9,15]$. For a physical adsorption, it is also expected that the value of Ea should be less than $80 \mathrm{~kJ} / \mathrm{mol}$ [32]. From Table 2, it is seen that the values of Ea obtained with TALE were less than $80 \mathrm{~kJ} / \mathrm{mol}$.

\section{Conclusion}

Treculia Africana leaves extract was found to be an inhibitor for aluminium in $\mathrm{HCl}$ solution. Inhibition efficiency increased with increase in inhibitor concentration. The increase in temperature reduces the inhibition efficiency. Negative values of Qads were obtained indicating physical adsorption. The adsorption process of TALE followed Freundlich and El-Awady adsorption isotherms and first order kinetics was followed. In general, the physical adsorption phenomenon is proposed.

\section{References}

1. Zhumdahl SS. Chemistry. 3rd ed. Lexington, Toronto, Canada: DC Heath and Co; 1993.

2. Obot IB, Obi-Egbedi NO, Umoren SA. Int J Electrochem. Sci. 2009;4:863877.

3. Umoren SA, Obot IB, Akpabio LE, Etuk SE. Pigment Resin Technol. 2008;37(2):98-105.

4. Noor EA. Int J Electrochem Sci. 2007;2:996-1017.

5. Subha R, Saratha R. J Corr Sci Eng. 2006;10:1-8. Preprint 9.

6. El-Etre AY. J Colloid Interf Sci. 2007;31:578-583.

7. Oguzie EE. Corrosion Sci. 2007;49:1527-1539.

8. Rahim AA, Rocca E, Steinmetz J, Kassim MJ, Adnan R, Ibrahim SM. Corrosion Sci. 2007;49:402-417.

9. Oguzie EE, Onuchukwu AI, Okafor PC, Ebenso EE. Pig Resin Technol. 2006;35(2):63-70.

10. El-Etre AY, El-Tantary Z. Port Electrochim Acta. 2006;24(3):347-356.

11. Obot IB, Obi-Egbedi NO. Int J Electrochem Sci. 2009;4:1277-1288.

12. Umoren SA, Obot IB, Obi-Egbedi NO. J Material Sci. 2009;44:274-279.

13. Umoren SA, Obot IB, Ebenso EE, Obi-Egbedi NO. Port Electrochim Acta. 2008;26:199-209.

14. Raja PB, Rahim AA, Osman H, Awang K. Acta Physico-Chimica Sinica. 2010;26(8):2171-2176.

15. Nnanna LA, Onwuagba BN, Mejeha IM, Okeoma KB. Afri J Pure Appl Chem. 2010;4(2):11-16.

16. Etukudoh I. Ethnobotany: Conventional and Traditional Use of Plant. Uyo, Nigeria: Verdict Press; 2003.

17. Eddy NO, Ita BI, Ibisi NE, Ebenso EE. Int J Electrochem Sci. 2011;6:10271044. 
18. Evans WC. Trease and Evans Pharmacognosy. 15th ed. New York: Elsevier Science Limited; 2002.

19. Harbone BJ. Phytochemical Methods-A Guide to Modern Techniques of Plant Analysis. London: Chapman and Hall; 1998.

20. Umoren SA. Cellulose. 2008;15:751-761.

21. Oladele SK, Okoro HK. African J Biotechnol. 2011;10(16):3152-3156.

22. Eddy NO, Ekwumemgbo PA, Mamza PAP. Green Chem Lett Rev. 2009;2(4) 223-231.

23. Solmaz R, Kardas G, Yaziei B, Erbil M. Protection Metals. 2005;41(6):581585.

24. Gunasekaran G, Chauhan LR. Electrochim Acta. 2004;49(25):4387-4395.

25. Dahmani M, Et-Touhami A, Al-Deyab SS, Hammouti B, Bouyanzer A. Int J Electrochem Sci. 2010;5:1060-1069.

26. Gogoi PK, Barhai B. Int J Electrochem Sci. 2011;6:136 -145.

27. James AO, Akaranta O. African J Pure Appl Chem. 2009;3(12):262-268.

28. James AO, Akaranta O. Res. J Chemical Sci. 2011;1(1):31-37.

29. James AO, Oforka NC, Abiola OK. Int J Electrochem Sci. 2007;2:278-284.

30. Quartarone G, Moretti G, Tassan A, Zingales A. Werkst Korrosion. 1994;45:34; in ref. 2.

31. Awad IM. J Appl Electrochem. 2006;36:1163-1168.

32. Eddy NO, Odoemelam SA, Ekwumemgbo P. Scientific Res Essay. 2008;4(1):33-38. 